\title{
Phytoplankton and microbial abundance and bloom dynamics in the upwelling shadow of Monterey Bay, California, from 2006 to 2013
}

\author{
Jennifer A. Schulien ${ }^{1,3, *}$, Melissa B. Peacock ${ }^{1,4}$, Kendra Hayashi $^{1}$, Pete Raimondi ${ }^{2}$, \\ Raphael M. Kudela ${ }^{1}$ \\ ${ }^{1}$ Ocean Sciences Department, University of California at Santa Cruz, Santa Cruz, CA 95064, USA \\ ${ }^{2}$ Ecology and Evolutionary Biology Department, University of California at Santa Cruz, Santa Cruz, CA 95064, USA \\ ${ }^{3}$ Botany and Plant Pathology, Oregon State University, Corvallis, OR 97331, USA \\ ${ }^{4}$ Present address: Northwest Indian College, 2522 Kwina Rd, Bellingham, WA 98226, USA
}

\begin{abstract}
Wind-driven upwelling variability and local topography cause an upwelling shadow in the northern region of Monterey Bay, California, to persist seasonally. The present study applied partial least squares regression to a 7 -yr time series collected within this retentive feature for the purpose of evaluating the environmental controls on total autotrophic phytoplankton (as chlorophyll a) and picoplankton (Synechococcus spp., picoeukaryotes, and heterotrophic bacteria) abundance. A bloom threshold was defined and applied to all biological groups to evaluate seasonal and inter-annual abundance patterns. Microbial and phytoplankton abundances in the upwelling shadow were positively associated with warmer, nutrient-depleted water. Consistent with these results, two-thirds of phytoplankton blooms occurred in October-November, when surface temperatures were warm and ammonium concentrations were greatest. These blooms were predominantly composed of dinoflagellates, $64 \%$ of which were known toxin-producing species. Although the overall relationship of phytoplankton to river discharge rates was negative, phytoplankton blooms in 2006, 2007, 2010, and 2012 followed early rainfall events, which flush nitrogen from the surrounding farms into the bay. Despite the fact that the regional measure of upwelling, the Bakun upwelling index, is seasonally low in the autumn, pulses of cold, nutrientreplete water were advected into the upwelling shadow, additionally supporting late-year blooms. Physical and chemical processes occurring over multiple time scales controlled bloom dynamics in the upwelling shadow of Monterey Bay.
\end{abstract}

KEY WORDS: Phytoplankton blooms · Phytoplankton dynamics $\cdot$ Upwelling shadow

\section{INTRODUCTION}

Monterey Bay, California, is a coastal open embayment located in the California Current System (CCS) on the eastern edge of the North Pacific gyre. The biological, chemical, and physical environment is strongly influenced by locally upwelled water and California Current water, which is advected onshore during relaxation events (Graham \& Largier 1997, Ryan et al. 2014). Local conditions in the bay are

*Corresponding author: schuliej@oregonstate.edu principally driven by the degree of upwelling (and relaxation), which in turn is controlled by the strength and direction of the alongshore winds and shelf topography (Pennington \& Chavez 2000, Wilkerson et al. 2000, Kudela et al. 2008a, Jacox \& Edwards 2011). Numerous watersheds empty into Monterey Bay, and rivers are an important source of nutrients (Kudela \& Chavez, 2004, Lane et al. 2009, Fischer et al. 2014). Furthermore, the land surrounding Monterey Bay has been intensively used for agri-

(C) The authors 2017. Open Access under Creative Commons by Attribution Licence. Use, distribution and reproduction are unrestricted. Authors and original publication must be credited. 
culture, and there is a clear anthropogenic signature in coastal nutrient loads (Chapin et al. 2004, Lane et al. 2009, Hughes et al. 2011) that appears to significantly impact phytoplankton community structure (Kudela et al. 2008b, 2010, Paerl et al. 2011).

The seasonal patterns in Monterey Bay are well described. The bay is typically divided into periods of upwelling and relaxation, and periods when the coastal poleward flowing Davidson Current surfaces (Skogsberg 1936, Bolin \& Abbott 1963, Breaker \& Broenkow 1994, Pennington \& Chavez 2000). The upwelling season, characterized by low temperature and high salinities, typically spans February to August. The oceanic season (August-November) follows upwelling. Upwelling-favorable winds relax and the California Current collapses onshore, leading to annual maxima in surface temperature and thermal stratification. Water temperature in the Davidson Current season is relatively warm and the water column is weakly stratified (Skogsberg 1936, Skogsberg \& Phelps 1946, Pennington \& Chavez 2000).

As a response to upwelling at Point Año Nuevo and regional topographical effects, shallow, stratified, cyclonic circulation can persist in the northern part of the bay (Breaker \& Broenkow 1994). Newly upwelled water flows into the bay, creating dynamic fronts where phytoplankton can become concentrated and the associated nutrient supply can support massive phytoplankton blooms (>100 $\mathrm{gg} \mathrm{l}^{-1}$; Kudela et al. 2008a, Ryan et al. 2008, 2014). Furthermore, when newly upwelled or California Current water flushes the bay, the upwelling shadow maintains the phytoplankton landward of the upwelling front and protects it from being flushed or dispersed (Graham \& Largier 1997, Ryan et al. 2009). This combination of processes sets up an environment that acts like a semi-enclosed embayment which insulates the bay from regional CCS processes. Upwelling shadows are found globally along eastern boundary coastlines and their unique physical and chemical structuring support environments favorable to harmful algal blooms (HABs; Pitcher et al. 2010).

Basin-scale variability, for example, the El NiñoSouthern Oscillation (ENSO), Pacific Decadal Oscillation (PDO), and North Pacific Gyre Oscillation (NPGO), also impact local patterns of phytoplankton abundance and composition in the CCS. ENSO events have significant effects on the chemical, physical, and biological structure of Monterey Bay and directly impact rates of phytoplankton primary production (Chavez 1996, Wang \& Fiedler 2006, Bjorkstedt et al. 2011). DiLorenzo et al. (2013) found that the PDO and NPGO control low-frequency upwelling dynamics and these periods capture the decadal expression of El Niño events throughout the extratropics (eastern Pacific and Central Pacific El Niños, respectively). Cloern et al. (2007) found the PDO to directly control phytoplankton community composition in San Francisco Bay, and their study encouraged us to include these climate indices in our analysis.

The 2 primary objectives of this work were to identify and understand the environmental conditions that influence phytoplankton community composition across multiple time scales and evaluate total chlorophyll $a$ and picoplankton bloom dynamics using a 7-yr, weekly time series from the Santa Cruz Municipal Wharf (SCMW). This work builds on previous studies in the southern CCS (Anderson et al. 2008, Kim et al. 2009, Venrick 2012) and northern CCS (Du et al. 2015) that looked at environmental controls on nearshore phytoplankton abundance and community composition. These coastal time series are most relevant to human interactions with the ocean, while more open ocean time series may not be capturing all the dynamics that are occurring.

\section{MATERIALS AND METHODS}

\section{Data sets}

Discrete water samples were collected approximately weekly from August 2006 to December 2013, initially as part of the California Program for Regional Enhanced Monitoring for Phyco Toxins (CalPReEMPT, 2006), and later as part of the Central and Northern California Ocean Observing System (CeNCOOS, 2007-2013) at the SCMW $\left(36.9633^{\circ} \mathrm{N}\right.$, $122.0172^{\circ} \mathrm{W}$ ) (Fig. 1). Biological and environmental variables included in this study are listed in Table 1 and the processing methods used are described below. United States Geological Survey (USGS) stream gage river discharge rates for the Salinas, San Lorenzo, Pajaro and Soquel Rivers were downloaded from the USGS database (http://waterdata.usgs.gov/ nwis/). The Pajaro, Soquel, San Lorenzo and Salinas Rivers were chosen for this study because they were identified by Lane et al. (2009) to best predict toxigenic diatom blooms (a biological response) in this region. We downloaded the Bakun Upwelling Index (BUI; Bakun 1990) for the Monterey Bay region $\left(36^{\circ} \mathrm{N}, 122^{\circ} \mathrm{W}\right)$ from the NOAA database (www.pfeg. noaa.gov/products/PFEL). The Multivariate ENSO 


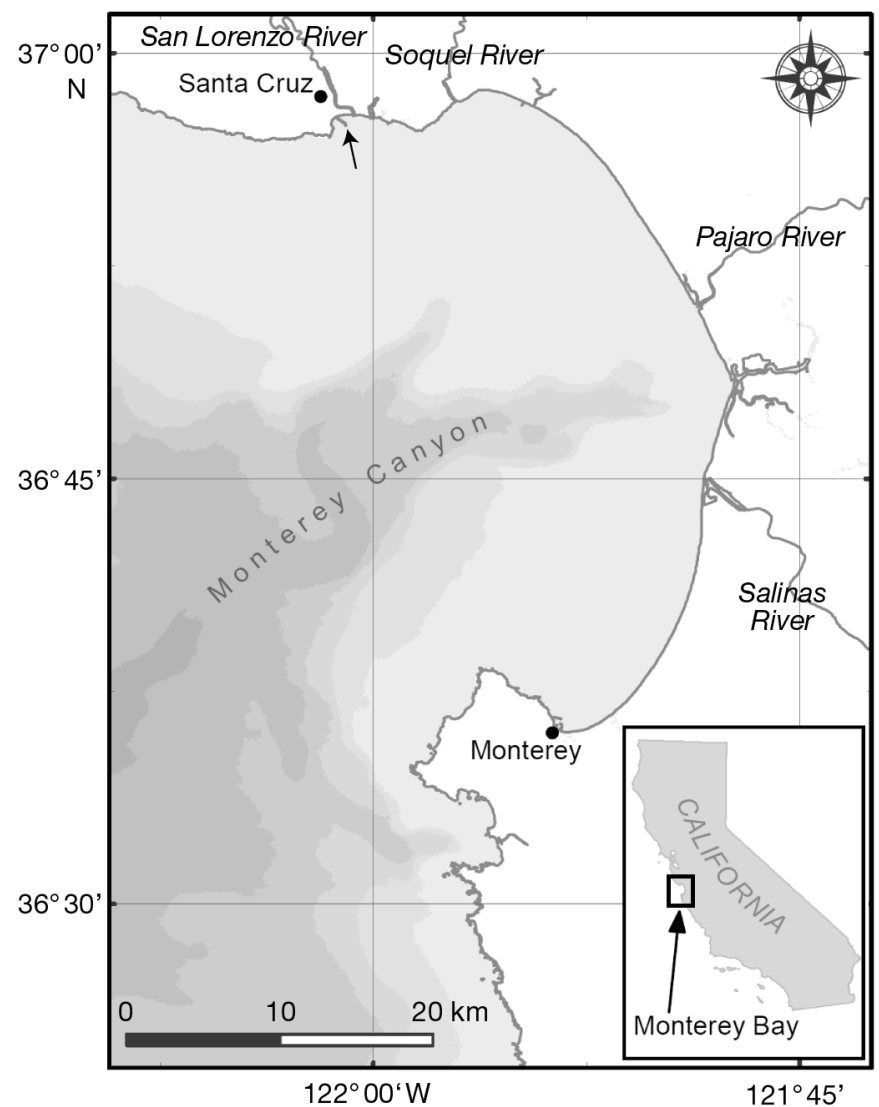

Fig. 1. Monterey Bay, California. Samples were collected at the Santa Cruz Municipal Wharf. Inset shows location of Monterey Bay in California

Index (MEI) (www.esrl.noaa.gov/psd/enso/mei/index. html), PDO Index (http://jisao.washington.edu/pdo), and NPGO Index (www.o3d.org/npgo) were also downloaded and included in the analysis. The Regional Ocean Modeling System (ROMS) data were obtained from the JPL ROMS Monterey Nowcast system, provided by Yi Chao (Remote Sensing Solutions and UCLA). The data are currently archived on the Central and Northern California Ocean Observing System (CeNCOOS) THREDDS server at http:// legacy.cencoos.org/thredds/catalog.html.

\section{Discrete water sample analysis}

Approximately weekly samples were collected by collecting 21 of water from 3 depths $(0,1.5$, and $3 \mathrm{~m})$ using a Niskin bottle. This water was combined to create an integrated sample representative of the upper water column. Particles in the mixed layer, by definition, are homogeneous, but due to the presence of migrating phytoplankton, this is often not the case at the SCMW. This collection procedure ensured that actively migrating phytoplankton populations were included in sampling. Temperature of the integrated water sample was measured immediately following sample retrieval using a calibrated thermometer. Water for analysis of nitrate + nitrite (hereafter referred to as nitrate, $\left.\mathrm{NO}_{3}{ }^{-}\right)$, phosphate $\left(\mathrm{PO}_{4}{ }^{3-}\right)$, and silicate $\left(\mathrm{SiO}_{4}{ }^{2-}\right)$ was filtered through a Whatman $\mathrm{GF} / \mathrm{F}$ filter (nominal pore size $0.7 \mu \mathrm{m}$ ) and analyzed using a Lachat QuikChem 8000 Series (Lachat Instruments, Hach Company) (Smith \& Bogren 2001, Knepel \& Bogren 2002). Samples for $\mathrm{NH}_{4}^{+}$and urea measurements were collected and processed according to the methods outlined in Holmes et al. (1999) and Price \& Harrison (1987). Chlorophyll a (chl a) samples (35 ml)

Table 1. Variables used in the statistical analyses. For the partial least-squares regressions, $\mathrm{N}=299$ for all variables. EOF: empirical orthogonal function; SST: sea surface temperature; SSH: sea surface height

\begin{tabular}{|c|c|c|c|c|}
\hline Variable type & Variable & Units & Range (median) & $\begin{array}{c}\text { Trans- } \\
\text { formation }\end{array}$ \\
\hline Environmental & Temperature & ${ }^{\circ} \mathrm{C}$ & $8.8-17.2(13.0)$ & $\log _{10}$ \\
\hline Environmental & Ammonium & $\mu \mathrm{M}$ & $0-52.1(1.6)$ & $\log _{10}$ \\
\hline Environmental & Urea & $\mu \mathrm{M}$ & $0-15.9(0.6)$ & $\log _{10}$ \\
\hline Environmental & Nitrate & $\mu \mathrm{M}$ & $0-24.0(2.6)$ & $\log _{10}$ \\
\hline Environmental & Phosphate & $\mu \mathrm{M}$ & $0-4.7(0.8)$ & $\log _{10}$ \\
\hline Environmental & Silicate & $\mu \mathrm{M}$ & $0.5-67.4(13.4)$ & $\log _{10}$ \\
\hline Environmental & River Discharge & $\mathrm{ft}^{3} \mathrm{~s}^{-1}$ & $2.9-10684.0(67.9)$ & $\log _{10}$ \\
\hline Environmental & Pacific Decadal Oscillation Index & 1st EOF SST & $-2.3-0.8(-0.9)$ & None \\
\hline Environmental & North Pacific Gyre Oscillation Index & 2nd EOF SSH & $0.6-2.5(1.4)$ & None \\
\hline Environmental & Multivariate ENSO Index & 1st EOF of 6 variables & $-2.0-1.5(-0.5)$ & None \\
\hline Environmental & Bakun Upwelling Index & $\mathrm{m}^{3} \mathrm{~s}^{-1} 100 \mathrm{~m}^{-1}$ coastline & $-256-640(66)$ & $\log _{10}$ \\
\hline Biological & Chlorophyll a & $\mu \mathrm{g} \mathrm{l}^{-1}$ & $0.40-201.90(5.65)$ & $\log _{10}$ \\
\hline Biological & Heterotrophic bacteria & cells ml ${ }^{-1}$ & $1.31 \times 10^{5}-1.08 \times 10^{7}\left(1.65 \times 10^{6}\right)$ & $\log _{10}$ \\
\hline Biological & Synechococcus spp. & cells ml $\mathrm{m}^{-1}$ & $51-3.21 \times 10^{5}\left(7.55 \times 10^{3}\right)$ & $\log _{10}$ \\
\hline Biological & Picoeukaryotes & cells ml $\mathrm{ml}^{-1}$ & $65-5.91 \times 10^{4}\left(6.70 \times 10^{3}\right)$ & $\log _{10}$ \\
\hline
\end{tabular}


were collected using Whatman GF/F filters and analyzed using the non-acidified fluorometric technique on a 10-AU Turner fluorometer (Welschmeyer 1994). All samples were run at either the University of California Santa Cruz Biological Oceanography Laboratory or the Marine Analytical Laboratory.

The phytoplankton relative abundance index (RAI) is a qualitative index of phytoplankton abundance for species greater than $\sim 30 \mu \mathrm{m}$ and easily observable smaller chain-forming species. This RAI ranges from 0 to 4 , with 0 being absent and 4 being greater than $50 \%$ of any given sample $(0=$ absent; $1=<1 \% ; 2=1-10 \% ; 3=11-50 \% ; 4=$ $>50 \%$ ) (Jester et al. 2009). As a qualitative index, the RAI is used to evaluate trends and understand temporal dynamics of larger phytoplankton. Of the phytoplankton observed at the SCMW, Alexandrium catenella and Pseudo-nitzschia spp. were identified as HAB-forming groups. Dinophysis spp., Cochlodinium spp., Lingulodinium polyedrum, Gonyaulax spinifera, and Akashiwo sanguinea are known to cause harmful bloom events in the Monterey Bay region, and were also identified as HAB species. To convert the RAI to percent composition, we assigned to the observation the mean percentage value of the index range. We added these values together and set this new value to $100 \%$.

\section{Picoplankton abundance by flow cytometry}

Samples collected for flow cytometric (FCM) analysis were fixed with $4 \%$ paraformaldehyde and stored in the dark at $-80^{\circ} \mathrm{C}$. Three major groups of picoplankton were characterized and enumerated: heterotrophic bacteria (HBAC), Synechococcus spp. (SYN), and picoeukaryotes (PICO). The samples were analyzed on a Becton Dickinson Influx flow cytometer (BD Biosciences) equipped with a $200 \mathrm{~mW}$ laser exciting at $488 \mathrm{~nm}$. Auto-fluorescing beads (SPHERO Ultra Rainbow Fluorescent Particles, $0.5-3.0 \mu \mathrm{m}$ diameter) were added to samples prior to analysis for size validation. Samples were run at $\sim 25 \mu \mathrm{min}^{-1}$ for $2 \mathrm{~min}$ and a volumetric estimate of cell density was determined according to Goebel et al. (2008) and Peacock \& Kudela (2012). Each sample was characterized by its forward angle light scatter ( $F S C$; relates to particle size), orange fluorescence emission from phycoerythrin $(527 \pm 27 \mathrm{~nm})$, and red fluorescence emission from chl a $(692 \pm 40 \mathrm{~nm})$, to enumerate SYN and PICO. Samples collected from October-December 2007, May-August 2009, and November-December 2009 were preserved in contaminated paraformaldehyde and were thus discarded, reducing the overall number of weekly samples by 34 .

To count HBAC, the nucleic acid stain SYBR Green I (Molecular Probes) was added and FSC and fluorescence emission at $531 \pm 30 \mathrm{~nm}$ were used to identify the population. Sample preparation was carried out in subdued light. SYBR I was diluted 1:20 from the manufacturer concentration with $0.22 \mu \mathrm{m}$ filtered deionized water. Each $0.75 \mathrm{ml}$ sample had $1 \mu \mathrm{l}$ diluted SYBR I added. Optimal incubation time was determined by performing a time-series experiment taking HBAC measurements every 1-5 min for 60 min. A 15-min dark incubation was chosen based on this analysis. We concluded that the stain was no longer working effectively for samples collected from May to August 2013 because the beads were present in expected concentrations while the HBAC concentrations were orders of magnitude below the expected values. This reduced the HBAC dataset by 15 samples. For all SYN, PICO, and HBAC samples, FlowJo software (Tree Star) was used to analyze and obtain a volumetric estimate of cell density (Goebel et al. 2008, Peacock \& Kudela 2012).

\section{Statistics}

\section{Partial least squares regression}

The relationships between environmental variables (urea, $\mathrm{NH}_{4}{ }^{+}, \mathrm{NO}_{3}{ }^{-}, \mathrm{PO}_{4}{ }^{3-}, \mathrm{SiO}_{4}{ }^{2-}$, BUI, river discharge, NPGO, PDO and ENSO) and biological variables (chl $a, \mathrm{PICO}, \mathrm{SYN}, \mathrm{HBAC}$ ) were evaluated using partial least squares regression (PLSR). PLSR is particularly appropriate when there is autocorrelation among predictor variables (Carrascal et al. 2009). In PLSR, the environmental variables first are grouped into axes of variability called components, which are specifically oriented with respect to the dependent biological variable. Therefore, for each of the 4 regressions, the environmental variables loaded differently in each component in order to maximize the amount of variability explained by the model. The loading values for the environmental variables are a measure of how much variability is explained within the component. The number of components chosen for model inclusion was determined by analyzing plots of (1) mean squared error (MSE) versus component number, and (2) percent variance explained by each component. Thus, the predictability of the model was maximized while the error was minimized. Prior to analysis, all variables 
(Table 1) were tested for normality, and log-transformed to reduce heteroscedasticity. Environmental data were standardized by computing their standard score (subtracted the mean and divided by the standard deviation for each dataset). To evaluate whether any time lags between variables existed, we used the cross-correlation function $(\mathrm{CCF})$ in Systat Version 14.0 .

\section{Bloom analysis}

The bloom threshold was calculated for each group (chl a, PICO, SYN, HBAC) as the 95\% prediction interval. These values were obtained by calculating the $z$-scores from the observational means and standard deviations of the transformed dataset. We also ran the chl a bloom analysis with the threshold set to 2 standard deviations above the mean to test how sensitive the analysis was to threshold choice. These bloom thresholds are specific to the SCMW dataset and do not necessarily provide information about blooms at other locations. Smayda (1997) extensively discussed the issues with defining a 'bloom'. Several studies, including Kim et al. (2009) and Carstensen et al. (2007), have applied the standard deviation-based approach used here.

\section{RESULTS}

\section{Oceanographic conditions}

The discrete samples from August 2006 through December 2013 and the monthly means are shown in Fig. 2. Sea surface temperature ranged from 8.8 to $17.6^{\circ} \mathrm{C}$, with a median value of $13.0^{\circ} \mathrm{C}$. Minimum temperatures occurred from December to February, and maximum temperatures occurred from August to September annually. $\mathrm{NO}_{3}{ }^{-}$ranged from $\leq 0.14$ to $24 \mu \mathrm{M}$ (median $=2.4 \mu \mathrm{M})$. The highest concentrations were observed from January through March, and the lowest concentrations persisted from July through October, varying inversely relative to temperature in the annual cycle. Covarying with $\mathrm{NO}_{3}{ }^{-}, \mathrm{PO}_{4}{ }^{3-}$ ranged from $\leq 0.02$ to $4.7 \mu \mathrm{M}$ (median $=0.8 \mu \mathrm{M})$, and $\mathrm{SiO}_{4}{ }^{2-}$ ranged from 0.5 to $67.4 \mu \mathrm{M}$ (median $=13.1 \mu \mathrm{M}$ ). Ammonium concentrations ranged from $\leq 0.02$ to $52.1 \mu \mathrm{M}$ (median = $1.6 \mu \mathrm{M})$, and had maximum concentrations from October through December. Urea concentrations ranged from $\leq 0.02$ to $15.85 \mu \mathrm{M}$ (median $=0.69 \mu \mathrm{M})$, with maximum concentrations in August and September.

\section{Chlorophyll $a$ and picoplankton abundance}

Trends in chl a and RAI for the 7-yr time-series from August 2006 to December 2013 are presented in Fig. 3. Chl a ranged from 0.40 to $289.1 \mu \mathrm{g} \mathrm{l}^{-1}$ (median $\left.=5.65 \mu \mathrm{g} \mathrm{l}^{-1}\right)$. Minimum concentrations occurred from December through March and elevated concentrations persisted from April through November. Two periods of elevated phytoplankton biomass were recorded each year. The bloom in the oceanic period was larger in magnitude and duration than the spring bloom for all years except 2008 and 2009. The phytoplankton community in the early upwelling season was typically dominated by diatoms, whereas dinoflagellates dominated during late upwelling and oceanic periods.

Trends in picoplankton abundance for the 7-yr time series from August 2006 through December 2013 are presented in Fig. 4. HBAC abundance ranged from $1.31 \times 10^{5}$ to $1.08 \times 10^{7} \mathrm{cells} \mathrm{ml}^{-1}$ $\left(\right.$ median $=1.65 \times 10^{6}$ cells ml $\left.^{-1}\right)$. Abundance of HBAC was elevated beginning in May and remained high until November, with the greatest abundance in September and October. The abundance of SYN ranged from 51 to $3.21 \times 10^{5}$ cells ml $^{-1}$ (median $=7.55$ $\times 10^{3}$ cells $\mathrm{ml}^{-1}$ ). Relatively elevated SYN concentrations typically occurred twice per year, in JanuaryMarch and September-October. Abundance of PICO ranged from 65 to $5.91 \times 10^{4}$ cells ml $^{-1}($ median $=6.70$ $\times 10^{3}$ cells ml $\mathrm{m}^{-1}$ ). There was no visually apparent seasonal pattern in PICO concentrations.

\section{Partial least squares regressions}

PLSR was compared with traditional principal components regression, and was found to significantly improve model parameters ( $p$-value, $r^{2}$, and mean squared error [MSE]). Chl a was set as the dependent variable in the PLSR, and when 3 environmental components were included, a statistically significant model ( $p<0.001)$ was produced with an $r^{2}$ value of 0.30. In the first component, which explained $19 \%$ of

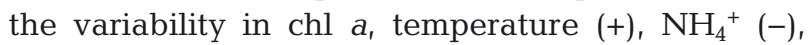
$\mathrm{NO}_{3}{ }^{-}(-), \mathrm{PO}_{4}{ }^{3-}(-)$, and to a lesser extent $\mathrm{SiO}_{4}{ }^{2-}(-)$ and urea (-) had the highest loading values (Fig. 5). CCF was used to evaluate whether there was a time lag between high phytoplankton abundance and $\mathrm{NO}_{3}{ }^{-}$. A significant (at the $\alpha=0.05$ level) $0-2 \mathrm{wk}$ time lag was observed, indicating that significant changes in the phytoplankton community occur within the first 2 wk of changed $\mathrm{NO}_{3}{ }^{-}$. Temperature (-) and NPGO (-) primarily loaded in the second component, 

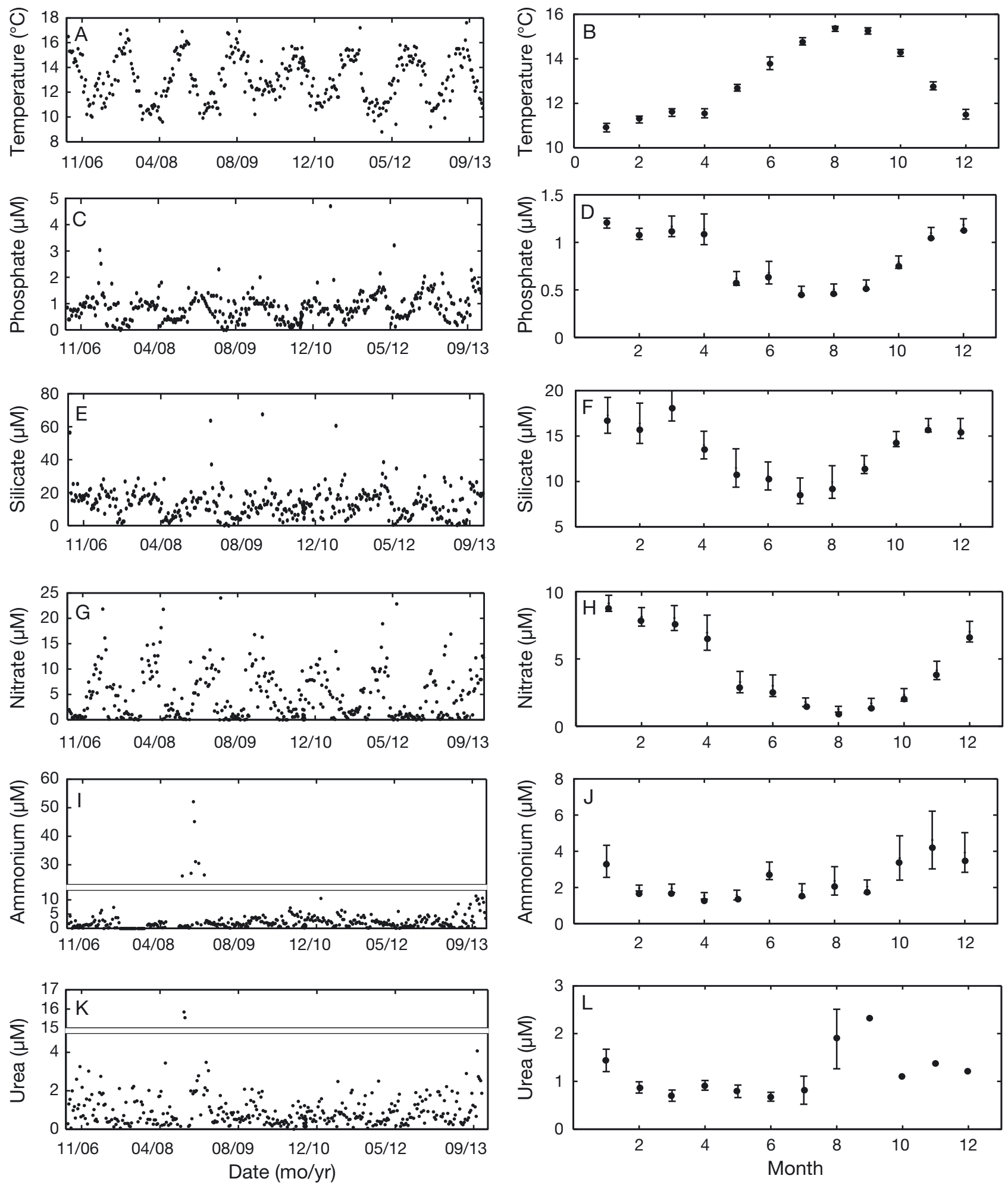

Fig. 2. Seven-year weekly time series (left panels) and monthly means (right panels; August 2006-December 2013) of (A,B) temperature, $(\mathrm{C}, \mathrm{D})$ phosphate, $(\mathrm{E}, \mathrm{F})$ silicate, $(\mathrm{G}, \mathrm{H})$ nitrate, $(\mathrm{I}, \mathrm{J})$ ammonium, and $(\mathrm{K}, \mathrm{L})$ urea collected at the Santa Cruz Municipal Wharf. Weekly samples were collected by combining 21 water from 3 depths $(0,1.5$, and $3 \mathrm{~m})$, which created an integrated sample representative of the upper water column. This collection procedure ensured that actively migrating phytoplankton populations were included in sampling. The bars on the right plots represent one standard deviation. NB $y$-axes in (I) and

(K) are non-continuous 

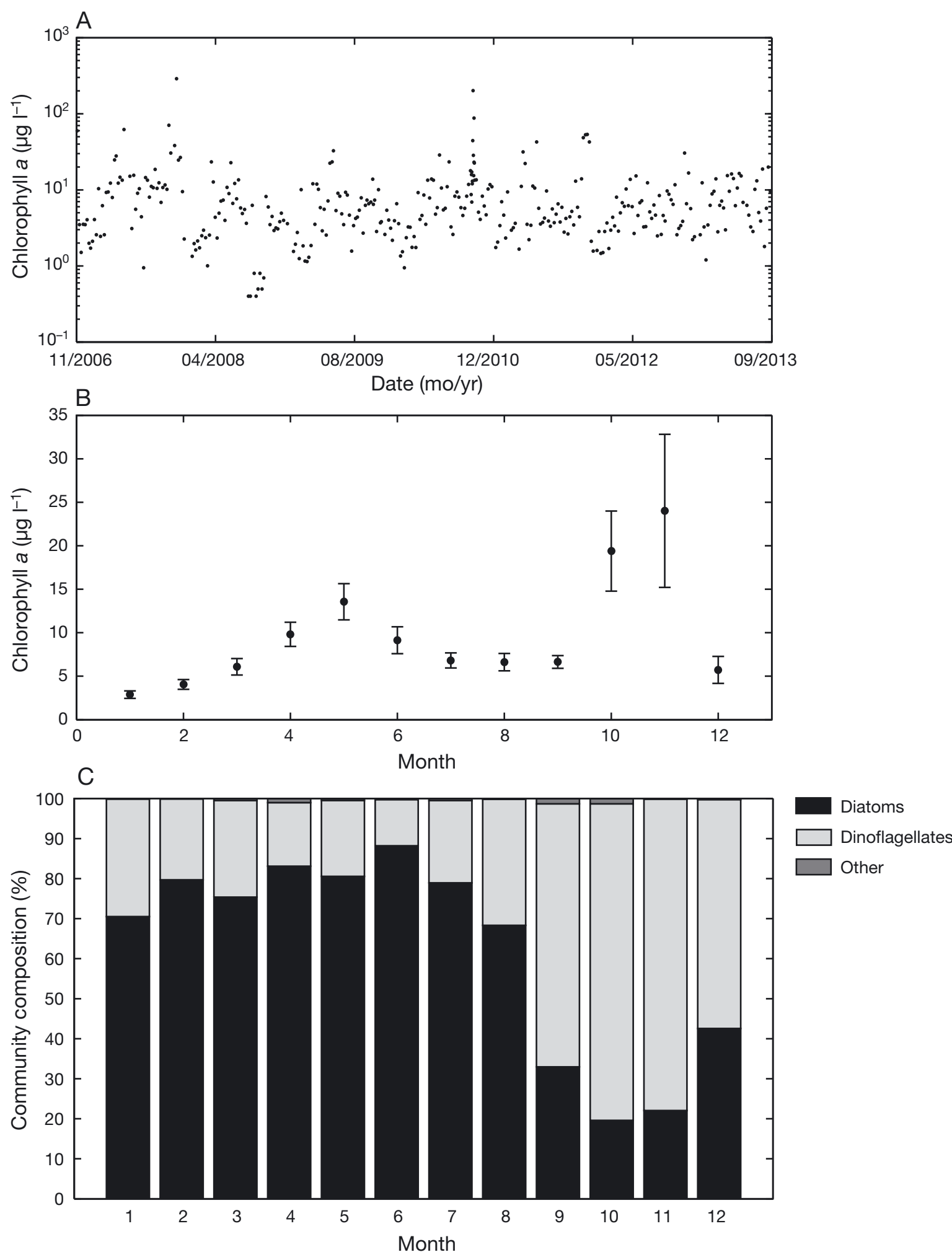

Fig. 3. (A) Seven-year weekly time series of $\log _{10}$-transformed chlorophyll a. (B) Monthly averages ( \pm SD) for the same time series. (C) Percent composition of the $>30 \mu \mathrm{m}$-sized phytoplankton from the relative abundance index (RAI), which is an index ranging from 0 to 4 . To convert the RAI to percent composition, we assigned to the observation the mean percentage value of the index range. We then added these values together and set this new value to $100 \%$. The groups shown are 'diatoms', 'dinoflagellates' or 'other', a group that includes Dictyocha sp. and Pheocystis sp. Differences between monthly averages calculated using the maximum and minimum values of the RAI range were calculated. The average difference for all groups was less than $1 \%$ 

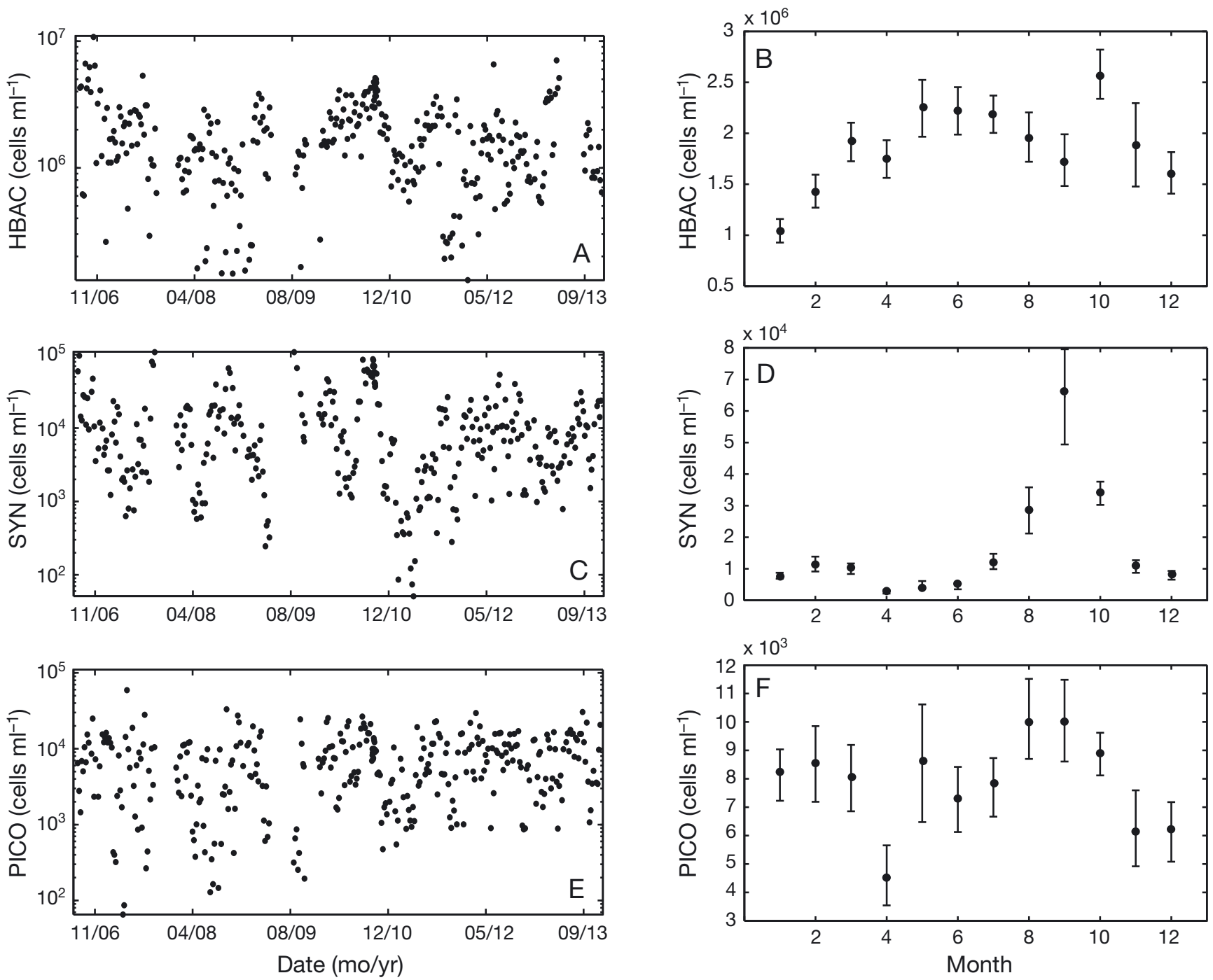

Fig. 4. Picoplankton concentrations and monthly means. Numbers on $x$-axis indicate month of year. The error bars on the right plots represent one standard deviation. HBAC: heterotrophic bacteria; PICO: picoeukaryotes; SYN: Synechococcus spp.

which explained $8 \%$ of the chl a variability. River discharge solely loaded the third component and explained $3 \%$ of the variability.

Including only the first 2 environmental components in the final regressions produced statistically significant models with the lowest MSE values for all picoplankton groups. The first environmental component when HBAC was set as the dependent variable was very similar to the first environmental component from the chl a PLSR: temperature (+), $\mathrm{NH}_{4}^{+}(-), \mathrm{NO}_{3}^{-}(-), \mathrm{PO}_{4}{ }^{3-}(-)$, and, to a lesser extent, $\mathrm{SiO}_{4}{ }^{2-}(-)$ and urea (-) had the highest loading values (Fig. 5). This component explained 13\% of the variability in the HBAC abundance data. River discharge $(+)$, PDO (+), and NPGO (-) had the highest loading values in the second component, which explained $3 \%$ of the HBAC variance.
The $\mathrm{p}$-value and $\mathrm{r}^{2}$ for this regression are $<0.001$ and 0.16 , respectively.

In the first environmental component related to SYN abundance, temperature (+), $\mathrm{NO}_{3}{ }^{-}(-), \mathrm{PO}_{4}{ }^{3-}(-)$, and river discharge $(-)$ had the highest loading values and explained $18 \%$ of the variability (Fig. 5). $\mathrm{SiO}_{4}{ }^{2-}(+)$ and BUI (-) had the highest loadings in the second component, which explained $6 \%$ of SYN variability $\left(\mathrm{r}^{2}=0.24\right)$. The $\mathrm{p}$-value for this model was $<0.001$.

In contrast to the regressions predicting $\mathrm{chl} a$, HBAC, and SYN, PLSR only explained $6 \%\left(\mathrm{r}^{2}=\right.$ 0.056) of the variability in PICO abundance ( $p<$ 0.001). Like the other biological groups, temperature $(+), \mathrm{NO}_{3}{ }^{-}(-), \mathrm{PO}_{4}{ }^{3-}(-)$, and, to a lesser extent, $\mathrm{NH}_{4}{ }^{+}$ $(-)$ and $\mathrm{SiO}_{4}{ }^{2-}(-)$ had the highest loading values in the first component, which explained $4 \%$ of the vari- 

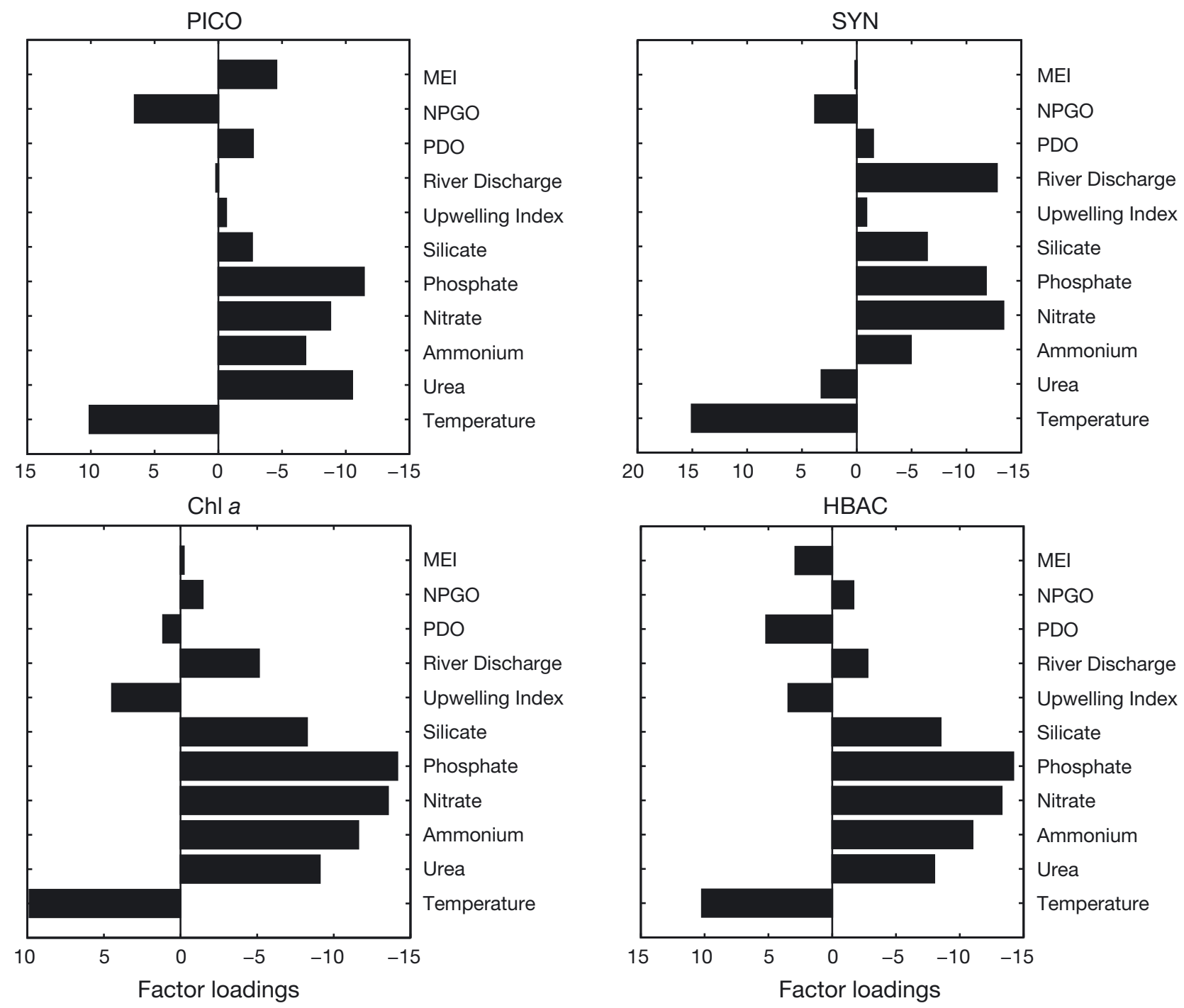

Fig. 5. First components of partial least-squares regressions (PLSR). The positive and negative loadings associated with the first PLSR component for each biological group are shown. PDO: Pacific Decadal Oscillation Index; NPGO: North Pacific Gyre Oscillation Index; MEI: Multivariate ENSO Index

ability (Fig. 5). The second component was primarily loaded by river discharge $(+), \mathrm{NO}_{3}^{-}(+)$, and $\mathrm{SiO}_{4}{ }^{2-}(+)$ and explained $2 \%$ of the variability.

\section{Bloom analysis}

Nineteen phytoplankton bloom events $(5.2 \%$ of the chl a dataset) were identified and occurred from April through December. Concentrations ranged from 27.8 to $289.1 \mu \mathrm{g} \mathrm{l}^{-1}$. The maximum concentration was observed on 14 November 2007 (289.1 $\mu \mathrm{g}$ $\mathrm{l}^{-1}$ ) during a red tide event primarily composed of the dinoflagellate Akashiwo sanguinea. A total of $57 \%$ of the phytoplankton blooms during the 7-yr time series occurred during the oceanic season and these blooms were primarily composed of dinoflagellates based on the RAI. Seventy-eight percent of the phytoplankton blooms occurred during the oceanic season when the bloom threshold was set to 2 standard deviations above the mean. There were no phytoplankton blooms in 2008 and 2009 using these thresholds. These correspond to the years where the monthly mean chlorophyll concentration was larger in the upwelling than the oceanic season.

Blooms for all biological groups are shown in Fig. 6. Eleven HBAC bloom events $(3.4 \%$ of HBAC dataset) were identified and occurred between May and November. Blooms ranged from $4.38 \times$ $10^{6}$ to $1.08 \times 10^{7}$ cells $\mathrm{ml}^{-1}$. A total of $44 \%$ of the major HBAC bloom events occurred in AugustNovember 2006, concurrent with another large red 


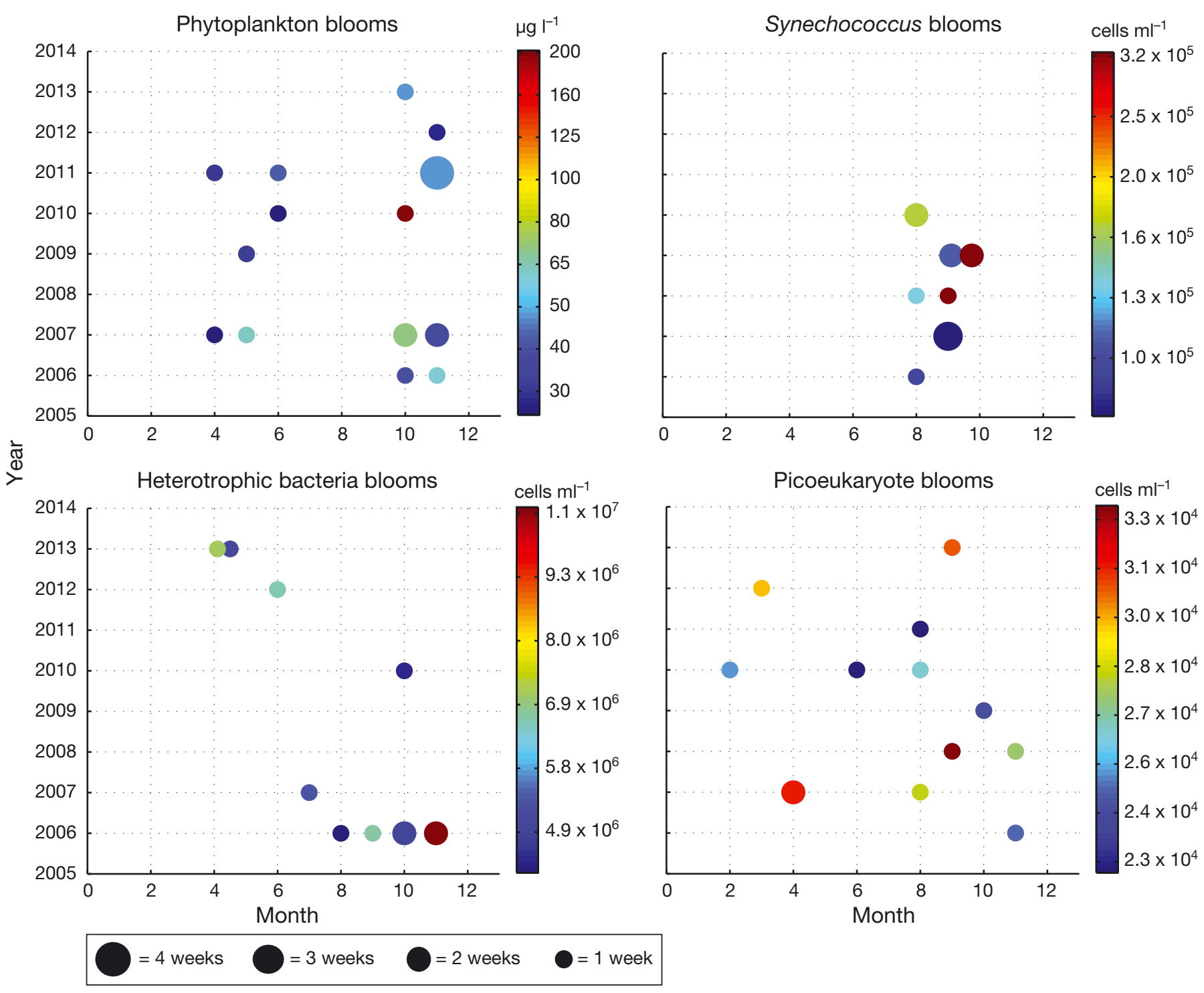

Fig. 6. Blooms of pico- and phytoplankton. Month is shown on the $x$-axis and year on the $y$-axis. The marker size is related to bloom duration, which ranges from 1 to 4 , and the color indicates average concentration over the bloom period

tide event that persisted in Monterey Bay during summer and autumn of that year (Kudela et al. 2008b).

Twelve SYN bloom events (3.5\% of SYN dataset) occurred from August to October. SYN bloom abundances ranged from $7.22 \times 10^{4}$ to $3.21 \times 10^{5}$ cells ml $^{-1}$. Although there is a visually apparent smaller peak of SYN in February in every year, this was not identified as a statistically significant major bloom using these thresholds. The maximum value was observed on 23 September $2009\left(3.21 \times 10^{5}\right.$ cells ml$\left.^{-1}\right)$, and no blooms were identified from 2011 to 2013. Thirteen PICO bloom events (3.8\% of PICO dataset) were identified, and occurred in all months (and years) except December-January and July. Blooms ranged from $2.29 \times 10^{4}$ to $5.91 \times 10^{4}$ cells $\mathrm{ml}^{-1}$.

\section{DISCUSSION}

\section{Environmental controls on biological groups}

Contrary to other evidence that indicates chl $a$ is increasing in the CCS (Anderson et al. 2008, Kim et al. 2009, McGaraghan \& Kudela 2012, Kahru et al. 2012), our weekly 7-yr time series from the SCMW did not show an increase in bloom magnitude over the time period examined in this study (Kendall's tau 
$\mathrm{p}=0.47$. Fluvial and sub-nutricline inputs can support high phytoplankton biomass, decoupling this area from larger, regional-scale processes. For example, during periods of weak or no upwelling, rivers (Kudela et al. 2010) and internal tides (Shea \& Broenkow 1982) transport inorganic macronutrients and urea to the northern region of Monterey Bay. Although negatively related to river discharge rates, which reach maximal values in winter, blooms were often preceded by early winter rainstorms. Anthropogenic pollutants accumulate during dry weather and then are washed away into rivers, storm drains, and the ocean during winter rainstorms. The first winter rainstorm flushes months of built-up pollutants, including nitrogen, into Monterey Bay. Early winter rainfall events preceded blooms in 2006, 2007, 2010, and 2012.

Despite the fact that regional upwelling is seasonally low during the oceanic period, the second phytoplankton bloom in 2006 and the blooms in 2011 and 2013 occurred following upwelling/relaxation events identified using the BUI, nitrogen, and sea surface temperature datasets. This is consistent with PLSR results, which predict a positive relationship between BUI and chl $a$. These upwelling/relaxation events occurred on monthly time scales ( 2 wk-2 mo). Thus, it appears that upwelling-derived and fluvial sources of nitrogen may support phytoplankton blooms during the oceanic period.

Of the major phytoplankton blooms that occurred during the oceanic season, all were primarily composed of dinoflagellates, of which $64 \%$ were known toxin-producing species. Dinoflagellates found in upwelling systems have been shown to exhibit higher than expected affinities for $\mathrm{NO}_{3}{ }^{-}$and medium affinities for $\mathrm{NH}_{4}{ }^{+}$, and are thus adapted for both low or pulsed $\mathrm{NO}_{3}{ }^{-}$and moderate to high $\mathrm{NH}_{4}{ }^{+}$concentrations (Kudela et al. 2010). Concentrations of $\mathrm{NH}_{4}{ }^{+}$ were highest in October-November, suggesting that phytoplankton that are able to rapidly utilize this form of nitrogen would have a competitive advantage during this season.

The ability to vertically migrate has been shown to give dinoflagellates a competitive advantage in stratified conditions. Regional Ocean Modeling System (ROMS) data from 2009 to 2013 (3 $\times 3 \mathrm{~km}$ box centered roughly at $36.9383,-122.0103$ ) indicate stratification was approximately equal in the early upwelling and oceanic bloom periods, which suggests that stratification was not a primary determinant of community composition on seasonal time scales. The coldest sea surface temperatures at the SCMW were observed in 2008 and 2009, and according to the
ROMS output, which begins in 2009, 2009 was the most weakly stratified year. Additionally, no oceanic blooms were identified in 2008 and 2009. Thus, it appears that the conditions that set up a stratified system are essential for the formation of oceanic (autumn) blooms on annual time scales.

The final regression model yielded an $\mathrm{r}^{2}$ of 0.30 , indicating that processes operating on time scales other than weekly contribute to the abundance variability of this group. Pulses of N-replete freshwater and newly upwelled water are just a couple of sources. Fischer et al. (2014) showed that the tidally influenced Elkhorn Slough plume can become entrained in the northward flowing nearshore current, and deliver nutrients to the northern part of Monterey Bay. Ryan et al. (2010) found that canyon nutrient pumping (tidally driven) was likely the main source of nutrients fueling the period of elevated phytoplankton biomass. Thus, there are multiple sources of sub-weekly nutrient variability in Monterey Bay's upwelling shadow. Environmental variables not included in the analysis could also drive chlorophyll concentrations at the SCMW.

The PLSR explained $16 \%$ of the variability in the weekly HBAC values. The independent variables included in the PLSR were the environmental variables, excluding chl a. HBAC abundances are expected to correlate with chlorophyll and planktonic primary production (Cole et al. 1988, Biermann et al. 2014). HBAC abundance followed this expected pattern, with blooms occurring primarily in the oceanic season when the concentration of chl a in Monterey Bay reached maximum values. We used a Type I linear regression of the $\log _{10}$-transformed HBAC and $\mathrm{chl}$ a datasets to evaluate how much of HBAC variability is explained by $\mathrm{chl} a$. The $\mathrm{r}^{2}$ and p-value for this model were 0.12 and $<0.05$, respectively. Therefore, a large amount of weekly variability in HBAC abundance pattern remains largely unexplained. The $\mathrm{r}^{2}$ and $\mathrm{p}$-values for the seasonally and annually averaged HBAC and chl a datasets were $0.7,<0.05$ and $0.6,<0.05$, respectively, for the seasonal and annual models. HBAC is thus correlated with chl $a$ on seasonal and annual time scales.

Synechococcus spp. were also expected to thrive in warm conditions with stronger stratification (Agawin et al. 1998, Paerl et al. 2012, Zhang et al. 2013). PLSR results were consistent with this expectation. SYN was associated with warmer temperatures, depleted nutrients, and low river flow. Blooms of SYN occurred from August to October, when temperature (SCMW, ROMS) and stratification (ROMS) were greatest. Organic nitrogen, specifically urea, concen- 
trations are high when SYN bloom. It has been demonstrated with cultures (Sakamoto \& Bryant 2001, Moore et al. 2002) and in the CCS (Toledo \& Palenik 1997) that Synechococcus spp. utilize urea for growth.

The negative response of SYN to river flow could be a response to several environmental changes associated with high/low river flow, including changes in dissolved organic carbon (DOC) (Kudela \& Chavez 2004), nutrient ratios (Lane et al. 2009), elevated trace metal concentrations (e.g. $\mathrm{Cu}^{2+}$; Paerl et al. 2011), or bacteriophage concentration (Lu et al. 2001). In the Pearl River Estuary in southern China, Zhang et al. (2013) observed a similar negative response between river discharge and Synechococcus spp. abundance. Crosbie \& Furnas (2001) also found a negative relationship between Synechococcus spp. and river runoff on shelf waters of the Great Barrier Reef, and attributed this relationship to salinity changes. Other potential mechanisms not measured in the present study, such as viral lysogeny, could play a role in controlling abundances of biological groups. McDaniel et al. (2002) found viral induction in natural population of marine Synechococcus spp. occurred seasonally, primarily in the winter. Viral pathogens were not the primary controllers of seasonal abundance, however, but rather enhanced the effects of nutrient limitation or adverse environmental conditions (McDaniel et al. 2002).

Despite the expected general dominance of large cells with low surface to volume ratios during the oceanic season (Wilkerson et al. 2000, Garibotti et al. 2003, Collins et al. 2003, Kudela et al. 2005), SYN were important members of the phytoplankton community in terms of numbers and biomass (using carbon conversions from Graff et al. 2012). PICO abundance remained relatively constant throughout the year despite the taxonomic diversity of this group, consistent with expectations. A lower PLSR coefficient of determination was observed likely because there is no robust relationship between PICO abundance and the environmental variables included in the analysis.

\section{SUMMARY AND CONCLUSIONS}

Elevated phytoplankton biomass was observed twice yearly at the SCMW. Unlike the pattern observed in other CCS studies, monthly averages of chl $a$ at the SCMW during the late upwelling and oceanic periods were greater in magnitude than during the early upwelling spring season, and com- posed primarily of dinoflagellates. Both riverine and upwelling-derived nutrients supported phytoplankton growth. The climate indices PDO and NPGO were most important in the models explaining HBAC and PICO abundances, but not for SYN. PDO, NPGO, and river discharge loaded most heavily in the second component in the chl a PLSR. These models describe the weekly abundance data and it is possible that the time series is not long enough to adequately quantify the effects of decadal-scale variability on phytoplankton abundance patterns at the SCMW.

The results of this study emphasize the importance of local monitoring as part of larger CCS studies, but also a local hotspot for HAB formation. Localized threats can also become regional if HABs are advected outside the upwelling shadow. For example, in November-December 2007, a bloom of Akashiwo sanguinea first observed in the northern region of the bay moved offshore and caused widespread seabird mortality (Jessup et al. 2009), while multiple other process studies have highlighted the importance of the northern Monterey Bay as a retentive 'hotspot' and the importance of advection in fostering blooms (Ryan et al. 2005, 2008, 2009, Das et al. 2012, Shulman et al. 2012). Networks of monitoring systems to capture coastal variability can provide important observations for a more comprehensive picture of CCS processes. Our analysis strongly supports the recommendation from Frolov et al. (2013) who, in the context of HAB monitoring, advocated for a combination of shore station sampling with limited, optimally placed offshore (shelf) assets to identify biological responses to oceanic forcing that occurs at local scales as well as at the mesoscale and basin scale.

Funding was provided by the NOAA Monitoring and Event Response for Harmful Algal Blooms (MERHAB) Award NA04NOS4780239 (Cal-PReEMPT), NOAA Ecology and Oceanography of Harmful Algal Blooms (ECOHAB) Award NA11NOS4780030, and NOAA IOOS through the Central and Northern California Ocean Observing System (CeNCOOS). This is ECOHAB Publication \#888 and MERHAB \#206.

\section{LITERATURE CITED}

Agawin NSR, Duarte CM, Agustí S (1998) Growth and abundance of Synechococcus sp. in a Mediterranean Bay: seasonality and relationship with temperature. Mar Ecol Prog Ser 170:45-53

Anderson CR, Siegel DA, Brzezinski MA, Guillocheau N (2008) Controls on temporal patterns in phytoplankton community structure in the Santa Barbara Channel, California. J Geophys Res 113:C04038 
Bakun A (1990) Global climate change and intensification of coastal ocean upwelling. Science 247:198-201

Biermann A, Engel A, Riebesell U (2014) Changes in organic matter cycling in a planktonic community exposed to warming under different light intensities. J Plankton Res 36:658-671

Bjorkstedt EP, Goericke R, McClatchie S, Weber E and others (2011) State of the California Current 2010-2011: regionally variable responses to a strong (but fleeting?) La Niña. CalCOFI Rep 52:36-68

Bolin RF, Abbott DP (1963) Studies on the marine climate and phytoplankton of the central coastal area of California, 1954-1960. CalCOFI Rep 9:23-45

Breaker LC, Broenkow WW (1994) The circulation of Monterey Bay and related processes. Oceanogr Mar Biol Annu Rev 32:1-64

* Carrascal LM, Galván I, Gordo O (2009) Partial least squares regression as an alternative to current regression methods used in ecology. Oikos 118:681-690

Carstensen J, Henriksen P, Heiskanen AS (2007) Summer algal blooms in shallow estuaries: definition, mechanisms, and link to eutrophication. Limnol Oceanogr 52:370-384

* Chapin TP, Caffrey JM, Jannasch HW, Coletti LJ, Haskins JC, Johnson KS (2004) Nitrate sources and sinks in Elkhorn Slough, California: results from long-term continuous in situ nitrate analyzers. Estuaries 27:882-894

* Chavez FP (1996) Forcing and biological impact of onset of the 1992 El Niño in central California. Geophys Res Lett 23:265-268

Cloern JE, Jassby AD, Thompson JK, Hieb KA (2007) A cold phase of the East Pacific triggers new phytoplankton blooms in San Francisco Bay. Proc Natl Acad Sci USA 104:18561-18565

Cole JJ, Findlay S, Pace ML (1988) Bacterial production in fresh and saltwater ecosystems: a cross-system overview. Mar Ecol Prog Ser 43:1-10

* Collins CA, Pennington JT, Castro CG, Rago TA, Chavez FP (2003) The California Current system off Monterey Bay, California: physical and biological coupling. Deep Sea Res II 50:2389-2404

* Crosbie ND, Furnas MJ (2001) Abundance, distribution and flow-cytometric characterization of picoeukaryote populations in central $\left(17^{\circ} \mathrm{S}\right)$ and southern $\left(20^{\circ} \mathrm{S}\right)$ shelf waters of the Great Barrier Reef. J Plankton Res 23:809-828

* Das J, Py F, Maughan T, O'Reilly T and others (2012) Coordinated sampling of dynamic oceanographic features with underwater vehicles and drifters. Int J Robot Res 31: 626-646

Di Lorenzo E, Combes V, Keister JE, Strub PT and others (2013) Synthesis of Pacific Ocean climate and ecosystem dynamics. Oceanography 26:68-81

* Du X, Peterson W, O'Higgins L (2015) Interannual variations in phytoplankton community structure in the northern California Current during the upwelling seasons of 20012010. Mar Ecol Prog Ser 519:75-87

* Fischer AM, Ryan JP, Levesque C, Welschmeyer N (2014) Characterizing estuarine plume discharge into the coastal ocean using fatty acid biomarkers and pigment analysis. Mar Environ Res 99:106-116

* Frolov S, Kudela RM, Bellingham JG (2013) Monitoring of harmful algal blooms in the era of diminishing resources: a case study of the US West Coast. Harmful Algae 21-22: $1-12$

Garibotti IA, Vernet M, Ferrario ME, Smith RC, Ross RM, Quetin LB (2003) Phytoplankton spatial distribution patterns along the western Antarctic Peninsula (Southern Ocean). Mar Ecol Prog Ser 261:21-39

*Goebel NL, Edwards CA, Carter BJ, Achilles KM, Zehr JP (2008) Growth and carbon content of three different sized diazotrophic cyanobacteria observed in the subtropical North Pacific. J Phycol 44:1212-1220

*Graff JR, Milligan AJ, Behrenfeld MJ (2012) Measurement of phytoplankton biomass using flow cytometric sorting and elemental analysis of carbon. Limnol Oceanogr Methods 10:910-920

Graham WM, Largier JL (1997) Upwelling shadows as a nearshore retention sites: the example of northern Monterey Bay. Cont Shelf Res 17:509-532

*Holmes RM, Aminot A, Kerouel R, Hooker BA, Peterson BJ (1999) A simple and precise method for measuring ammonium in marine and freshwater ecosystems. Can J Fish Aquat Sci 56:1801-1808

*Hughes BB, Haskins JC, Wasson K, Watson E (2011) Identifying factors that influence expression of eutrophication in a central California estuary. Mar Ecol Prog Ser 439: 31-43

* Jacox MG, Edwards CA (2011) Effects of stratification and shelf slope on nutrient supply in coastal upwelling regions. J Geophys Res 116:C03019

* Jessup DA, Miller MA, Ryan JP, Nevins HM and others (2009) Mass stranding of marine birds caused by a surfactant-producing red tide. PLOS ONE 4:e4550

* Jester R, Lefebvre K, Langlois G, Vigilant V, Baugh K, Silver MW (2009) A shift in the dominant toxin-producing algal species in central California alters phycotoxins in food webs. Harmful Algae 8:291-298

*Kahru M, Kudela RM, Manzano-Sarabia M, Mitchell BG (2012) Trends in the surface chlorophyll of the California Current: merging data from multiple ocean color satellites. Deep Sea Res II 77:89-98

Kim HJ, Miller AJ, McGowan J, Carter ML (2009) Coastal phytoplankton blooms in the Southern California Bight. Prog Oceanogr 82:137-147

Knepel K, Bogren K (2002) Determination of orthophosphate by flow injection analysis. QuikChem Method 31-115. Revised 2002. Lachat Instruments, Milwaukee, WI

Kudela RM, Chavez FP (2004) The impact of coastal runoff on ocean color during an El Niño year in Central California. Deep Sea Res II 51:1173-1185

Kudela RM, Pitcher G, Probyn T, Figueiras F, Moita T, Trainer V (2005) Harmful algal blooms in coastal upwelling systems. Oceanography 18:184-197

Kudela RM, Banas NS, Barth JA, Frame ER and others (2008a) New insights into the controls and mechanisms of plankton productivity in coastal upwelling waters of the Northern California Current System. Oceanography 21:46-59

Kudela RM, Lane JQ, Cochlan WP (2008b) The potential role of anthropogenically derived nitrogen in the growth of harmful algae in California, USA. Harmful Algae 8: 103-110

Kudela RM, Seeyave S, Cochlan WP (2010) The role of nutrients in regulation and promotion of harmful algal blooms in upwelling systems. Prog Oceanogr 85:122-135

Lane JQ, Raimondi PT, Kudela RM (2009) Development of a logistic regression model for the prediction of toxigenic Pseudo-nitzschia blooms in Monterey Bay, California. Mar Ecol Prog Ser 383:37-51

* Lu J, Chen F, Hodson RE (2001) Distribution, isolation, host specificity, and diversity of cyanophages infecting mar- 
ine Synechococcus spp. in river estuaries. Appl Environ Microbiol 67:3285-3290

McDaniel L, Houchin LA, Williamson SJ, Paul JH (2002) Lysogeny in marine Synechococcus. Nature 415:496

McGaraghan AR, Kudela RM (2012) Estimating label particulate iron concentrations in coastal waters from remote sensing data. J Geophys Res 117:C02004

Moore LR, Post AF, Rocap G, Chisholm SW (2002) Utilization of different nitrogen sources by the marine cyanobacteria Prochlorococcus and Synechococcus. Limnol Oceanogr 47:989-996

Paerl RW, Johnson KS, Welsh RM, Worden AZ, Chavez FP, Zehr JP (2011) Differential distribution of Synechococcus subgroups across the California current system. Front Microbiol 2:59

Paerl RW, Turk KA, Beinart RA, Chavez FP, Zehr JP (2012) Seasonal change in the abundance of Synechococcus and multiple distinct phylotypes in Monterey Bay determined by $r b c L$ and narB quantitative PCR. Environ Microbiol 14:580-593

Peacock MB, Kudela RM (2012) A method for determining alkaline phosphatase activity in marine phytoplankton using spectrofluorometery. J Microbiol Methods 89: 209-212

Pennington JT, Chavez FP (2000) Seasonal fluctuations of temperature, salinity and primary production at station H3/M1 over 1989-1996 in Monterey Bay, California. Deep Sea Res II 47:947-973

Price NM, Harrison PJ (1987) Comparison of methods for the analysis of dissolved urea in seawater. Mar Biol 94: 307-317

Ryan JP, Dierrsen HM, Kudela RM, Scholin CA and others (2005) Coastal ocean physics and red tides: an example from Monterey Bay, California. Oceanography 18: 246-255

Ryan JP, Gower JFR, King SA, Bissett WP and others (2008) A coastal ocean extreme bloom incubator. Geophys Res Lett 35:L12602

Ryan JP, Fischer AM, Kudela RM, Gower JFR, King SA, Marin R III, Chevez FP (2009) Influences of upwelling and downwelling winds on red tide bloom dynamics in Monterey Bay, California. Cont Shelf Res 29:785-795

Ryan JP, McManus MA, Sullivan JM (2010) Interacting physical, chemical, and biological forcing of phytoplankton thin-layer variability in Monterey Bay, California. Cont Shelf Res 30:7-16

Ryan JP, McManus MA, Kudela RM, Artigas ML and others

Editorial responsibility: Toshi Nagata,

Kashiwanoha, Japan
(2014) Boundary influences on HAB phytoplankton ecology in a stratification-enhanced upwelling shadow. Deep Sea Res II 101:63-79

Sakamoto T, Bryant DA (2001) Requirement of nickel as an essential micronutrient for the utilization of urea in the marine cyanobacterium Synechococcus sp. PCC 7002. Microbes Environ 16:177-184

Shea RE, Broenkow WW (1982) The role of internal tides in the nutrient enrichment of Monterey Bay, California. Estuar Coast Shelf Sci 15:57-66

Shulman I, Penta B, Moline MA, Haddock SH, Anderson S, Oliver MJ, Sakalaukus P (2012) Can vertical migrations of dinoflagellates explain observed bioluminescence patterns during an upwelling event in Monterey Bay, California? J Geophys Res Oceans 117(C1):C01016

Skogsberg T (1936) Hydrography of Monterey Bay, California. Thermal conditions, 1929-1933. Trans Am Philos Soc 29:1-152

Skogsberg T, Phelps A (1946) Hydrography of Monterey Bay, California. Thermal conditions, Part II (1934-1937). Proc Am Philos Soc 90:350-386

Smayda TJ (1997) What is a bloom? A commentary. Limnol Oceanogr 42:1132-1136

Smith P, Bogren K (2001) Determination of nitrate and/or nitrite in brackish or seawater by flow injection analysis colorimetry. QuikChem Methods, 31-107: Saline Methods of Analysis. Lachat Instruments, Milwaukee, WI

Toledo G, Palenik B (1997) Synechococcus diversity in the California current as seen by RNA polymerase (rpoC1) gene sequences of isolated strains. Appl Environ Microbiol 63:4298-4303

Venrick EL (2012) Phytoplankton in the California Current system off southern California: changes in a changing environment. Prog Oceanogr 104:46-58

* Wang C, Fiedler PC (2006) ENSO variability and the eastern tropical Pacific: a review. Prog Oceanogr 69:239-266

*Welschmeyer NA (1994) Fluorometric analysis of chlorophyll $\mathrm{a}$ in the presence of chlorophyll $b$ and pheopigments. Limnol Oceanogr 39:1985-1992

*Wilkerson FP, Dugdale RC, Kudela RM, Chavez FP (2000) Biomass and Productivity in Monterey Bay, California: contribution of the large phytoplankton. Deep Sea Res II 47:1003-1022

Khang X, Shi Z, Ye F, Zeng Y, Huang X (2013) Picophytoplnakton abundance and distribution in three contrasting periods in the Pearl River Estuary, South China. Mar Freshw Res 64:692-705

Submitted: May 24, 2016; Accepted: April 5, 2017

Proofs received from author(s): May 17, 2017 